\title{
Investigating the drivers of product innovation in emerging markets: The African perspective
}

\author{
Victor Y. Atiase \\ International Centre for Transformational Entrepreneurship \\ Coventry University, UK
}

\section{Dennis Y. Dzansi}

Central University of Technology

Free State, South Africa

\section{Short Summary:}

African firms have made some significant progress in product innovation through human capital development and firm competitiveness. However, these firms need to continuously focus on talent hunting and development as well as strategic collaborations to reap the full benefit of product innovation.

\section{Key Points:}

1. Human capital development efforts in Africa has made a significant impact on product innovation

2. Firm competitiveness in African markets currently drives product innovation

3. Networking and strategic collaboration among African firms are weak and need to be enhanced to support product innovation.

JEL Classification codes: 015, 031, 032, 055

Acknowledgements: The authors acknowledge the Central University of Technology, Bloemfontein, South Africa for providing the necessary funding to undertake this research. We also want to acknowledge the support from the Director and colleagues at the International Centre for Transformational Entrepreneurship, Coventry University, United Kingdom in conducting this research. 


\section{Introduction}

In today's globalised and competitive business environment, the most strategic, successful, and forward-looking firms are driven by product innovation in their anticipation to meet the changing taste and sophistication of their clients (O'Regan, 2012; Fossas-Olalla et al, 2015). The Schumpeterian endogenous growth model argues that innovation is an important dimension for industrial competition and firm growth (Schumpeter, 1934). Typically, product innovation is a measure of a country's potential to generate new products as well as the ability of its firms to adapt and absorb suitable technologies (GEDI, 2017). Product innovation also refers to the development of new and improved products through designs or redesigns and its successful market penetration to meet the needs, wants and taste of consumers (Valencia et al. 2010). Product innovation is even more crucial for firms which operate in emerging markets where there are visible weaknesses in technology, patency, market stability and a host of other infrastructural challenges. Therefore, product innovation is recognised as a source of profitability, productivity and growth (Li et al, 2007; Valencia et al. 2010). Product innovation also increases a firm's ability to capture both local and foreign markets (Lentz and Mortensen, 2016). Apart from demonstrating tangibility for innovativeness, product innovation is also seen as one of the critical means of corporate renewal, survival and strategic foresight without which firms are likely to exit markets once dominated (Paliokaitè, Pačèsa, and Sarpong, 2014; Acemoglu and Dan, 2015; Engelma et al. 2017).

Even though there has been so much discussion about product innovation in the business circles, research regarding its key drivers remains unclear and there is conflicting evidence in the literature particularly for emerging markets (Ferna'ndez-Mesa et al. 2013). More importantly, very little is known about these drivers in the context of Africa where there are market inefficiencies and other logistical constraints (Atiase et al., 2018). Globally, the competitive business environment shaped largely by globalisation, technological evolution and accelerated product life cycles coupled with high consumer expectations has become the driving force behind product innovations (Costa, Fernández, and Dorrego, 2014). Alegre, Lapiedra, and Chiva (2006) argue that product innovation has become an important aspect of firm survival for three main reasons. Firstly, there is an intense international competition which domestic firms need to rival with. Secondly, the ever-demanding and changing nature of consumers is a driving factor. Finally, the technological advancement which has dominated both domestic and international markets have provided the driving force for product innovation. This implies that firms that are able to offer products to meet the needs 
and wants of their target customers are likely to strongly position themselves and enjoy a lot of competitive advantage over their peers.

The innovation literature is replete with various drivers which are essential for the innovative capacity development of firms. Organisational talent and skill, culture, industry competition, available collaborative networks and alliances, offshoring, suitable technology, research and development (R\&D), input from users are just a few of them (Naghavi and Ottaviano, 2009; Valencia et al., 2010; Ferna'ndez-Mesa et al. 2013). Of particular importance is the input from users of the products introduced by firms (Hippel, 2011). This is essential because research evidence has proven that about 80 percent of all important inventions across various industries were generated due to the input by users (Chatterji and Fabrizio, 2014). In most cases, users are able to improve a product's functionality through the provision of constructive feedback into the design process. Valencia et al. (2010) categorised these drivers into individual, organisational and environmental. Cucculelli et al. (2016) also indicated that the governance structure available in a firm may be a driving force for introducing innovative products. This is because, due to the fear of losing control, firms may be unwilling to introduce new products which are outside their existing competency domain. These drivers have necessitated product designs and redesigns over the years to meet these changing demands by incorporating new functional technologies as well as upgrading the quality of products (Blonigen et al. 2017).

Generally, most firms in emerging markets lack the kind of institutional support which is needed to drive innovation and Africa is of no exception (Egbetokun et al. 2016). Africa as an emerging market has seen slow growth in innovation due to several factors. Essentially, the calibre of human capital available, the type of economic infrastructure and the environmental dynamism which is expected to drive innovation in Africa remains shallow and unsupportive (Story, et al. 2015; Atiase et al. 2017). In this study therefore, the authors focused on three drivers of product innovation in Africa namely human capital, firm competitiveness and networking. The creativity literature postulates that the most innovative ideas in a firm come from the creative abilities of employees and such abilities need to be harnessed, developed and encouraged (Chatterji and Fabrizio, 2014). Firstly, the availability of requisite innovative ideas, skill, and talent in an organisation remains crucial for product innovation (Costa, Fernández, and Dorrego, 2014). Secondly, firm competitiveness which produces the kind of consciousness and awareness about market dynamism and consumer preferences drives product innovation (Hecker and Ganter, 2013). Finally, the ability of the 
firm to engage in corporative networks and alliances which supports the dissemination of innovative ideas, skills, knowledge and resource sharing provides the necessary platform for firms to innovate (Fossas-Olalla et al. 2015). This study has two main contributions to offer. Firstly, the study aims at contributing to the product innovation literature by highlighting the factors that are responsible for effective product innovation in a firm. Secondly, this study aims at deepening the understanding of the three main drivers as identified above that are responsible for product innovation among indigenous African firms. This is one of the few studies which has attempted to understand the drivers of product innovation in Africa. This study is organised into seven sections including the introduction. Whiles section 2 presents the background to the study, section 3 discusses the theoretical framework and the various hypotheses. Section 4 presents the research context and methodology for this study. Section 5 and 6 presents and discusses the results respectively. Section 7 concludes the study.

\section{Background}

\section{Product innovation}

Product innovation refers to the ability of a firm to introduce new and useful products to satisfy a market need through the exploitation of new ideas. At the country level, product innovation is a measure of a country's preparedness to adapt and absorb new technologies which are consistent and relevant to national conditions (GEDI, 2017). According to Alegre et al. (2006:333), product innovation consist of two main conditions namely "novelty" and "use". Product innovation is a process which consists of the technical design, R\&D, manufacturing and the management of all the commercial activities associated with the new or improved product (Alegre et al. 2006; Smith et al., 2012). Much more detail issues to consider in product innovation is its efficacy and efficiency which reflects the degree of success and effort associated with the innovation process (Ferna'ndez-Mesa et al. 2013).

Smith et al. (2012) indicate that all product innovations start with the design creativity which involves the visual perception of new concepts, plans and ideas which are usually presented diagrammatically in sketches. The design process engages the logical and intuitive thought which brings together the technical capabilities of the firm in consideration of consumer inputs (Deininger et al, 2017). Also, there is the need to redesign certain products in the firm due to several reasons such as the change in user requirements, improvement in quality, reduction in cost, extension in product life or even for environmental reasons (Smith et al. 
2012). It is therefore important for firms to overcome their design difficulties at the product design stages. This is essential because as pointed out by Smith et al. (2012), more than 75 percent of all engineering design activities in the firm reuse previous designs to design new products.

However, there are several factors which impede the design capability of firms such as unavailability of formal product development and innovation processes, lack of access to design resources, poor understanding of design and in most cases the lack of the required financial resources to support the design process particularly among SMEs (Ferna'ndez-Mesa et al., 2013). These factors according to Cucculelli et al. (2016) are detrimental to the ability of the firm to introduce new products through competency renewal and its consequential impact on firm performance. Following the design stage, firms usually come out with prototypes which allows both physical and visual form to be given to an innovative idea. Prototyping allows firms to identify and minimize design problems, meet user needs and verify design solutions (Deininger et al, 2017). In an effective innovative product development environment, Engelma et al. (2017) argue that the availability and the ability of the firm to absorb innovative capacity remains crucial to any product development process. In essence, this implies that all firms that intend to be competitive through their innovative products need to constantly absorb and improve their innovative capacity through training and re-training as well as engaging in collaborative networks which could improve their talent development. More importantly, firms should be able to adopt other strategies such as building into the process the voice of the consumer, team accountability, continuous improvement, lean manufacturing processes and openness to the external environment (Cooper and Edgett, 2008).

The above discussion so far points to the fact that new product development has much to do with the drivers behind such innovative products and how the commercial activities associated with the product is managed. Based on data from 17 countries, Evanschitzky et al, (2012) argue that only a quarter of all new products introduced at a time is successful. This implies that identifying the various drivers and success factors responsible for product innovations is very crucial. 


\section{Innovation in Africa}

Research on innovation in Africa is growing rapidly with various studies attempting to understand the factors which enable or inhibit the phenomenon. Most of these studies focus on the various sources of knowledge for innovation (Carlisle et al. 2013), the role of public policy (Iizuka and Gault, 2015), the role of technology adoption and absorption (Botchie, Sarpong, and $\mathrm{Bi}, 2017$ ) and the role of the various institutional factors (Egbetokun et al., 2016). Generally, most of the studies on African innovation focus on systemic weaknesses and constraints in the firm which inhibit innovation. However, the nature of these weaknesses and how to mitigate them remain unclear and unresolved at least for the present moment (Egbetokun et al., 2016). However, it is interesting to note that despite these weaknesses and constraints to innovation in African firms, quite a number of them are able to innovate both in product and processes (Egbetokun et al., 2016). For instance, an innovation survey conducted under the African Innovation Outlook by the AU-NEPAD (2014) across 11 African countries shows that innovative practices among African firms were of high levels. Table 1 below shows the findings from this survey.

Table I: Rate of innovation in selected African countries

>> Insert Table I here $<<<$

Source: Adapted from AU-NEPAD (2014)

The table above shows that a large number of firms in Africa engage in one kind of innovation or the other despite the various challenges they encounter. More importantly, it has been observed that innovation in the respective countries does not really depend on the existing economic growth of the respective countries. Even poorer countries such as Uganda could be more innovative than richer ones like South Africa (Egbetokun et al, 2016). Generally, the innovation process among African firms are affected by factors such as poor R\&D, unavailability of skilled employees (Barasaa et al.,2017), poor institutional support (Oluwatobi, 2015), lack of employee motivation, improper managerial practices, lack of inter-departmental cooperation and knowledge exchange programmes, lack of effective network and interactions with external organisations (Egbetokun et al., 2016; Cusmano, Morrison, and Rabellotti, 2010), lack of financial resources and poor environmental dynamism (Story et al., 2015). In another vein, one of the major constraints facing most 
African firms is their disconnectedness from their sources of information and knowledge institutions which is critical for all innovation activities in the firm (Al-Bader et al. 2010). As argued by Egbetokun et al. (2016), innovation is a connected activity whereby the firm needs to depend on the various external sources of information such as consumers, suppliers and competitors. Again, the innovation survey of the African Innovation Outlook by the AUNEPAD (2014) across 8 African countries indicate that the sources of information for innovation activities among African firms is limited. Table II below presents the findings from this survey.

Table II: Sources of Information for Innovation in selected African countries.

>> Insert Table II here $<<<$

Source: Adapted from Egbetokun et al., (2016).

More so, Africa is lagging behind with an infrastructural gab of $\$ 31$ billion per year in terms of electricity generation and access to Information and Communication Technology (ICT) which is a cause to worry in delivering innovation in Africa (Egbetokun et al.,2016; Cui et al. 2016; Atiase et al. 2017). More importantly, even though Africa accounts for 12 percent of the World's population, the continent struggles to produce even 1 percent of the world's research output (Mwiti, 2015). This implies that R\&D output in Africa is very low compared to other continents and this is likely to impede all innovative efforts so far gained. This is because research on innovativeness should be a continuous process which is iterative in nature to improve the innovative process (Moses et al., 2012). With such a low infrastructural gab as indicated above with its associated acute lack of various kinds of resources including human capital, Africa is likely to struggle in its innovation efforts. The next section discusses creativity and how it enhances a firm's ability to engage in product innovation. 


\section{Theory and hypotheses development}

\section{Creativity theory and product innovation}

The generation of creative ideas in a firm is a pre-requisite for product innovation. Several decades of scholarly work on innovation focus on the creative ability of the individual as the driving force behind all innovative processes in the firm. Such levels of creativity have also been noted to be the major source of competitive advantage for firms (Im et al. 2013; Chatterji and Fabrizio, 2014). However, Duxbury (2012) argues that creativity as a concept is difficult to measure objectively because it relates much more to the context and the perception of the observer. Therefore, for firms to innovate properly there is the need to focus on the creative individual in order to augment the product innovation process. Creativity theory is therefore an important lens through which studies relating to product innovation could be undertaken. This is because, creativity is a necessary means to product innovation and serves as a stimulus for discovering new opportunities for innovation and other sources of competitive advantage (Duxbury, 2012). Three important components of creativity are evident in the literature. They are the creative individual, the creative process and the creative product (Kasirer and Mashal, 2018). Zhang and Sternberg (2011) also outline six factors responsible for creativity namely intelligence, knowledge, intellectual style, personality, motivation, and the environment. This implies that the level of product innovation which happens in a firm depends largely on the level of intelligence and creative ability of employees and other related parties including users (Baldwin and Hippel, 2011).

The theory of creativity prescribes that creativity happens in an organization due to the intrinsic creative ability of the individual to produce original products through their innovative ideas (Audretsch and Belitski, 2013). Cardoso de Sousa et al. (2012) indicate that creativity refers to the process of producing novelty which becomes accepted by a significant group of people at a particular time. Creative individuals are known to be spontaneous to thinking and persistent in seeking solutions to organisational challenges. Creative individuals are also found to be exploratory, optimistic, reactive to stimulation and tolerant of uncertainty (Hoffmann et al., 2018). Creative individuals are also found to be original, elaborate, and flexible in thinking which brings their creative abilities out. Barbot (2018:3) refers to this type of individual as the "creative self ". Barbot (2018:3) therefore argues that the real creative abilities of the individual comes from "domain relevant self-esteem", and creative self-esteem. 
The theory therefore lies in how each individual member of an organisation organises and incorporates his own perception and skill into a process, strives for mastery and perfection through the expression of one's individuality (Cardoso de Sousa et al. 2012). All firms that are innovative depends on the creative abilities of the individual either internally or externally to the organisation. These group of individuals are noted to be full of unique solutions to all kinds of organizational challenges including product design and innovation (Ip et al, 2018). On the other hand, Baer (2012) argue that creativity is domain specific and individual traits contribute very little to the creative performance of the individual. One of the big questions to answer in creativity theory is the degree to which individual skills vary from one domain to another due to the context in which such skills are exhibited (Chuang, 2007; Czerwonka and Karwowski, 2018). However, Cardoso de Sousa et al. (2012) pointed out that creativity is neither located in the creator nor the product but rather in the kind of interaction which exists between the product and the users. Therefore the level of interaction which exists between the originator of the product (the firm) and the users (consumers) remains useful to the product innovation process (Hippel, 2011). Based on the creativity theory, the various hypotheses are developed and presented below.

\section{Human capital and product innovation in the firm}

Several decades of research point to the fact that the availability of adequate and qualified human skill in the firm is known to form the innovative capability of the firm and it influences the type and nature of product innovation which occurs (Barney, 1991; Costa et al. 2014). Such intangible assets in the form of intellectual capital according to Costa et al. 2014 ) is the main source of product innovation performance and its continuous upgrade. Engelma et al. (2017) indicate that intellectual capital has the potential to create value and encourages the growth of synergies in the firm and could be damaged by high employee turnover. Human capital refers to all business capital which is embedded in employees but not owned by the organisation such as employees, intelligence, competencies, experiences, skills, attitude, knowledge and wisdom (Baer, 2012; Mohamud and Sarpong, 2016; Hoffmann, Ivcevic, and Maliakkal, 2018). Zhang and Sternberg (2011) put intelligence into three main categories namely the synthetic, analytical and practical. Whereas synthetic intelligence allows the individual to see and understand problems from a different perspective, analytical intelligence helps the individual to choose among alternative ideas to pursue. Finally, practical intelligence enables the individual to persuade others to accept a proposed innovative idea. 
Costa, Fernández, and Dorrego (2014) again emphasise that since product innovation is a knowledge absorption and creation process, it basically depends on how knowledge is created and shared in the firm. Engelma et al. (2017) therefore argue that it behoves on the firm to recruit, develop and retain the required level of intellectual capital in the respective areas of operation necessary for product innovation. Chatterji and Fabrizio (2014) also contend that intellectual knowledge may not only reside in the organisation but rather the users of a particular product could also provide some form of user-knowledge which contributes to radical innovations in the firm. This type of knowledge is usually valuable at the beginning of the product life-cycle where user-input is required for product modifications to meet consumer preferences and also to estimate the potential market size (Zhang et al., 2009). In developing a firm level knowledge to support product innovation, Audretsch and Belitski (2013) indicate that firms should be comfortable with developing suitable in-house knowledge which will help them gain a competitive advantage through "learning by doing" which serves as the basis for innovation in the firm. Based on the above discussion and evidence in the literature, the study hypothesised as follows:

\section{$\boldsymbol{H}_{1}$ : The quality of human capital is positively related to product innovation in the firm}

\section{Firm competitiveness as a source of product innovation}

As noted above, the competitiveness of the firm is derived from the presence of the creative and innovative abilities of the individuals in the firm. The argument is that it takes creativity to be competitive in the marketplace (Hecker and Ganter, 2013). Such a competition could further serve as a source of product innovation. While there exist some theoretical arguments regarding the relationship between competitiveness and firm innovative capability development, the innovation literature highlights competitiveness as one of the drivers of product innovation in the firm (Zhang et al., 2009; Hecker and Ganter, 2013). The premise of this hypothesis is found on the basis that, when a firm becomes competitive in a particular industry by developing suitable products to satisfy consumers, it could lead to product innovation through the application of various types of creative ideas in designing suitable products to satisfy consumers (Wu, 2012). Zhang et al. (2009) argue that a firm which aligns its strategies to the market conditions, as well as the competitive intensity, is likely to become synergetically viable in its product innovation performance. Such market level conditions may provide the opportunity for new knowledge exploitation and exploration. In a separate study, Hecker and Ganter (2013) pointed out that competitiveness increases the demand for 
exploitative innovation to enhance firm innovative performance. Without a firm becoming competitive by producing and marketing competing products to satisfy consumer needs and wants, it may seize to be innovative and this is likely to affect the drive towards product innovativeness in the firm. Based on the above discussion and evidence in the literature, the study hypothesised as follows:

$\boldsymbol{H}_{2}$ : A firm's competitiveness is positively related to product innovation in the firm

\section{Firm networking and collaborations lead to product innovation}

There is significant literature on the impact of collaborations and strategic alliances on the innovative capacity development of firms. A study by Wu (2012) using data from 944 Chinese firms across five manufacturing sectors provides evidence that product and technological collaborations enhance product innovation ability in firms. Strategic alliances and technical collaborations among firms is known to enhance the innovative capabilities of firms (Fichter, 2009; Minh and Hjorts $\varnothing$, 2015). This is because, when firms share knowledge on design and technologies that are common to them, they are able to intensify explorative knowledge in product innovations. Strategic alliances refer to voluntary arrangements where firms team up to enhance the development and commercialisation of new technologies and ideas in product innovations (Pittaway et al, 2004; Lyytinen et al. 2016).

Current observations show that, due to intense global competition, many firms are collaborating particularly in using various kinds of technology which reduces the cost of acquiring new technology as well as increasing the technical know-how of the firm. (Colombo et al, 2012; Amankwah-Amoah and Sarpong, 2014; Lyytinen et al. 2016). Firms that seek an exploratory strategy to innovate their products are likely to partner with firms they think are stronger and are able to enhance their opportunities (Hemphälä and Magnusson, 2012; Robbins and O'Gorman, 2015). Usually, alliances are opportunistic in nature which enables firms to strategically benefit from the resources in their networks (Minh and Hjorts $\varnothing, 2015$; Leenders and Dolfsma, 2016). Konsti-Laakso et al. (2012) also indicate that due to the resource constraints that particularly SMEs face, it is contingent upon them to form strategic alliances and networks which would enhance resource sharing in innovating their products. Both Konsti-Laakso et al. (2012) and West and Boger (2014) emphasise that user involvement and co-creation opportunities are essential alliances which firms can build to reduce the cost of production and launching of new products. Fossas-Olalla et al. (2015) 
also pointed out that technological collaborations with external partners such as suppliers can contribute to ideas in reducing manufacturing problems, risks, costs and complements the firms R\&D efforts in the product innovation processes.

Hofman et al. (2017) identify two types of networks which are essential for product innovation in the firm namely structural and positional networks. Whiles structural networks refer to the positional advantage of the individuals in the network which accrue to the organisation, the positional network focuses on the strength of the relationship between individuals in the network and how this can facilitate the sharing of knowledge and resources. These two types of networks determine to a large extent the organisational coupling among the innovation network partners. In some networks, there is exist coopetition which refers to the ability of firms to both cooperate as well as compete in the same market for their common good (Bengtsson et al. 2016). Based on the above discussion and evidence in the literature, the study hypothesised as follows:

\section{$\boldsymbol{H}_{3}$ : Firm networking is positively related to product innovation}

Based on the above discussion and considering the major findings from the literature, the following conceptual framework as shown in Figure I is proposed for this study in relation to the hypotheses presented above.

\footnotetext{
$\gg>$ Insert Figure I here $<<<$
}

Figure I: A hypothesised model for the drivers of product innovation in Africa

\section{Research context and methodology}

\section{Sample and data sources}

The main source of data for this study comes from the 2017 survey of the Global Entrepreneurship Index (GEI) for the 35 African countries (4 in North Africa and 31 in SubSaharan Africa) engaged in this study. Broadly, the GEI 2017 is an inter-country aggregate data from the Global Entrepreneurship and Development Institute (GEDI) survey which involved 508,009 individuals from 137 countries. The purpose of the GEDI survey is to undertake a comparative study of the entrepreneurial performance of the participating 
countries in terms of the quality and depth of the entrepreneurship eco-system across these countries (Acs, Szerb, Autio, and Lloyd, 2017). A total of 14 factors (pillars) were used to access the nature of the entrepreneurship ecosystem and how supportive it has been to entrepreneurs in Africa. Firstly, this study has used the tenth pillar of the GEI known as product innovation (PI) for the 35 Africa countries as the dependent variable (see Appendix II). According to GEDI (2017), product innovation is the measure of a country's potential to introduce new products and to imitate existing ones as well as practice technology transfers Secondly, human capital, networking, and firm competitiveness which are the $4^{\text {th }}, 8^{\text {th }}$ and $9^{\text {th }}$ pillars of the GEI were used respectively as predictor variables. Networking measures the ability of the firm or entrepreneur to relate or collaborate with others for a mutual benefit. Human capital measures the quality of human capital in the firm across the 35 African countries (GEDI, 2017). Firm competitiveness as a predictor variable measures the firm's product or market uniqueness in consideration of the market power of other competitors. Finally, the study used country-specific data including foreign direct investment (FDI), population and Gross Domestic Product (GDP) as control variables. All the data used in the regression analysis are in aggregate form. Appendix II and III give a full description of each of the variables. Table III below summarises the sources and types of data that were used in this study.

Table III: Summary of data sources and variables

$$
\text { >> Insert Table III here }<<<
$$

\section{Constructs and measurement}

\section{Dependent variable}

Product innovation is a pre-requisite for firms to gain or increase their market share and be able to compete globally to meet the demand, needs and wants of their consumers (Ferna'ndez-Mesa et al, 2013; Cucculelli et al. 2016). The dependent variable which is product innovation is the tenth pillar of the GEI, 2017 and it is based on aggregate data captured by two main items namely new product and technology transfer. The new product sub-variable measures the firm's ability to introduce new product and imitate existing ones. Technology transfer measures the firms business environment and whether it supports innovations for new products. This variable was measured on a seven-point Likert scale 
anchored by $(1=$ not able to introduce new products, $7=$ aggressive in introducing new products). The product innovation variable is therefore the mean of the two normalised subvariable scores. This score ranks African countries in terms of both country and firm-level product innovation. These items/sub-variables were adapted from the Global Entrepreneurship Monitor (GEM) Adult population survey (APS) which uses a questionnaire with a binary scale (yes/no) to collect the required data from both entrepreneurs and ownermanagers of African businesses. The respondents aged between 18 and 64 were asked to provide answers regarding new products and technology transfer variables (Reynolds et al., 2005; Sambharya and Musteen, 2014). Both reliability and validity tests were conducted on these variables. Using the Cronbach alpha test, the internal consistency of these variables was checked. Product innovation which is part of the ability pillars had a Cronbach alpha score of 0.91 which is greater than the usual threshold of 0.7 indicating a strong internal consistency of the construct. Secondly, the Kaiser-Meyer-Olkin measure of sampling adequacy and Bartlett's test of sphericity were conducted. The result indicates a 0.94 score for the original pillar values and 0.96 for the adjusted values which were also above the accepted critical threshold of 0.5 . The Bartlett's test was significant at the 0.000 level indicating a high confidence level of the model.

\section{Independent variables}

The study engaged three independent variables to explain product innovation in the African context. These variables are networking, human capital and firm competitiveness. These variables were chosen because as indicated above, it is believed these factors have a crucial role to play in the level of product innovation which takes place in a firm. All the three variables were sourced from the GEI, 2017 involving 35 African countries. Firstly, networking which is the $4^{\text {th }}$ pillar of the GEI measures the ability of the entrepreneur to connect or collaborate with others in similar or across other industries for their mutual interest. Networking has been used because the ability of the entrepreneur to network with others is an important ingredient for product innovation whereby access to various kinds of resources (knowledge and technology) could be accessed through those networks. Three (3) sub-variables were adopted to measure networking: the percentage of the population who know the entrepreneur, urbanisation and the quality of the transport infrastructure. The networking variable was measured on a seven-point Likert scale ranging from 1 to 7 . The 
networking variable which was used in the regression analysis is the mean of the three normalised sub-variables.

Secondly, the availability of high-quality human capital in a country and for that matter in the firm is crucial for firms that would make substantive progress in product innovation (GEDI, 2017). The human capital variable measures the quality of the human capital in the firm in terms of education, experience, staff training and labour market efficiency. Four (4) items/sub-variables namely educational level, labour market efficiency, staff training, and labour freedom were used to measure human capital. The mean of these items was used in the regression analysis.

Finally, competitiveness is an essential requirement for innovative firms whereby domestic firms in Africa compete both internally and externally to develop new products to meet market demand (Hecker and Ganter, 2013). The variable measures the product or market uniqueness of firms as well as the market power of competitors in the same industry. The competitiveness was measured using three (3) items/sub-variables namely competitors, market dominance and regulation. The mean of these variables was used in the regression analysis.

\section{Control variables}

This study was controlled using three (3) country-specific variables namely GDP, population and FDI for the 35 African countries. These variables were included in this study because these factors are considered to be able to influence the level of product innovation at the country level in Africa (Ahmed and Nwankwo, 2013). It is therefore important to understand the nature of the influence of these variables in the model used in this study.

\section{Results}

Table IV presents the descriptive statistics (i.e. means and standard deviations of the dependent and independent variables, minimum and maximum values, skewness, and Kurtosis of the variables). The results of the regression analysis regarding product innovation, explanatory and control variables appear in Table V. The regression model analysed networking, human capital and competition as drivers of product innovation among indigenous African firms. Two (2) regression models were executed. The first model which is the restricted model consist of the control variables (GDP, FDI and Population) and the dependent variable (PI). The second model which represents the full regression model 
consists of all the control variables, the predictor variables (networking, human capital and competition) and the dependent variable. The purpose of executing two models is to determine the influence of the control variables separately as well as to assess the overall fitness of the model.

Firstly, from the full regression model (Model 2), networking ( $p=0.888, \beta=0.024$ ) is statistically insignificant. The hypothesis regarding the positive impact of networking on product innovation in Africa is therefore rejected. Secondly, human capital $(p=0.012, \beta=$ 0.672 ) is statistically significant at 5 percent level. The hypothesis regarding the impact of human capital on product innovation in Africa is accepted. Accordingly, a unit increase in the quality of human capital increases product innovation by 67.2 percent. Finally, competitiveness ( $p=0.013, \beta=0.640)$ is statistically significant at 5 percent level. Therefore, the hypothesis regarding the impact of competitiveness on product innovation in Africa is accepted. Accordingly, a unit increase in the competitiveness of the firm would lead to a 64 percent increase in product innovation.

The results for the control variables are as follows: population ( $p=0.058, \beta=-1.387)$, FDI $(p=0.048, \beta=0.413)$ and GDP $(p=0.137, \beta=-1.649)$. The results indicate that whilst population is partially statistically significant at the 10 percent level, FDI is significant at 5 percent level. The level of FDI into Africa seems to have an influence on the level of product innovation among African firms. An increase in a unit of FDI into Africa could influence the level of product innovation by 41.3 percent. GDP is not significant and hence does not influence product innovation at the firm level in Africa.

The $R^{2}$ indicates the overall fitness of the regression model. From the full regression model, the $R^{2}$ value is 0.477 , and its adjusted value is 0.317 , thereby indicating that the full model explains 31.7 percent of the variance in product innovation. Tables IV and V below presents the descriptive statistics, correlations and results of the regression analysis respectively.

Table IV: Descriptive statistics and correlations

>> Insert Table IV here $<<<$

Table V: Regression analysis of the drivers of product innovation in Africa 
Based on the above analysis using the various independent, control and the dependent variable, the regression equation below is adapted for this study. Therefore, product innovation is predicted by:

$\mathrm{PI}=\alpha+\beta_{1} \mathrm{fdi}+\beta_{2} \mathrm{gdp}+\beta_{3} \mathrm{pop}+\beta_{4}$ netw $+\beta_{5}$ humc $+\beta_{6}$ comp $+\varepsilon$

Where: $\alpha=$ constant term, $\beta_{1}$ to $\beta_{6}=$ Regression coefficients, fdi $=$ Foreign direct investment, $g d p=$ Gross domestic product, $\mathrm{Pop}=$ Population, netw $=$ Networking, humc $=$ Human capital, $c 0 m p=$ Competitiveness and $\varepsilon=$ Error term.

\section{Discussion of results}

\section{Human capital makes a significant impact on product innovation in Africa}

Table $\mathrm{V}$ above shows the results of the regression analysis regarding networking, human capital and competitiveness as drivers of product innovation in indigenous African firms. Firstly, the result indicates that human capital makes a significant contribution to product innovation. As indicated in the previous discussions, no firm can be competitive in product innovation without the required qualified staff who are well trained with the requisite skills. Costa et al (2014) argue that no firm can progress effectively on the innovation trajectory without a properly trained staff who are creative and able to provide innovative ideas to generate new products and modify existing ones to satisfy market demand.

In a similar vein, Audretsch and Belitski (2013) indicate that firms should be willing to develop in-house knowledge as well as collaborate with others to generate essential knowledge which is important for product innovation. This implies that it is not just enough to generate knowledge internally, however firms should be able to generate external knowledge and intelligence through collaborations, user inputs, and suppliers (Baldwin and Hippel, 2011; Phillips et al, 2012; Chatterji and Fabrizio, 2014). The results therefore suggest that the current level of human capital in terms of the level of education of entrepreneurs, labour freedom and staff training in Africa supports product innovation. However, much more could be done in these areas to improve the level of product innovation on the continent. This evidence supports the findings of the African Innovation Outlook survey across 11 African countries which suggest that there is evidence of innovation across various firms (AU-NEPAD, 2014). 


\section{Firm competitiveness drives product innovation in Africa}

Secondly, the result also indicates that firm competitiveness in Africa drives product innovation. Market competition enables firms to seek both explorative and exploitative knowledge to improve their products in order to meet customer demands (Hecker and Ganter, 2013). Without industry competition, it is unlikely for firms in Africa to adopt a market approach to innovate their products. This is because monopolistic tendencies might stifle product innovation (Zhang et al. (2009). Competition could also provide the drive to seek other forms of collaboration in a form of co-opetition which could enhance knowledge sharing as well as other needed technological resources for a mutual benefit (Konsti-Laakso, Pihkala, and Kraus, 2012). The argument for market competition lies in the fact that consumers will determine the pace of product innovation at the firm level particularly if the firm is to retain its market share (Hippel, de Jong, and Flowers, 2012). The results of this study, therefore, suggest that the current level of competitiveness in African firms supports product innovation and this is likely to continue with a more stiffer competition which has been observed lately in the telecommunication and banking industries.

\section{Networking and strategic collaborations do not enhance product innovation in Africa}

Finally, the results suggest that networking, strategic alliances and collaborations is not one of the drivers for product innovation in Africa. Networking in the form of collaborations, strategic alliances and co-creation could be a valuable asset for firms in Africa (Wu, 2012). Similar studies in the UK find that 6.1 percent of consumers contribute largely to product innovations and spend about 2.3 times more on consumer innovation than all UK firms combined (Hippel, 2011). This is particularly important looking at the fact that many firms in Africa lack the kind of resources in the form of technology and the required technical skills which are needed to drive product innovation. Unlike other jurisdictions where collaborations are very common, African firms are unwilling to collaborate which would provide the platform to gain specialist knowledge as well as share resources. According to Colombo et al (2012), effective collaborations could reduce the cost associated with new product development as well as minimising technical challenges. Such networking could also take the form of co-creation where firms collaborate with users to create products which will meet the mutual needs of both the firm and users (West and Boger, 2014). Firms in Africa therefore have much to do in terms of collaborations to share specialist knowledge and other needed resources. In summary, the findings from this study indicate that there has been a 
considerable improvement in terms of meeting the human capital needs and firm industry competitiveness in Africa over the years. However, there is a need for Africa firms to engage in intensive technical and other forms of collaborations which can support the acquisition of technical knowledge and other perceived benefits.

\section{Conclusion}

Africa as the research context for this study provides an interesting and unique environment for a study of this nature which focusses on product innovation. Undoubtedly, a study of this nature would contribute to the improvement of the general framework for product innovation in Africa. The continent does seem to be doing well in terms of its human resource capacity development and firm competitiveness which enhances product development. However, much more is expected to be seen in the area of technical collaborations and strategic alliances in order to enhance the current level of innovation in the continent. This study aims at providing two main contributions. Firstly, the study has contributed to the innovation literature by highlighting the pertinent factors that are necessary for product innovation (Ferna'ndez-Mesa et al. 2013; Deininger et al, 2017). Secondly, this study by focussing on Africa and adopting creativity theory has deepened the understanding regarding the role of networking, human capital and competitiveness in product innovation. This is one of the few product innovation studies focusing on Africa. This study has implications for policy and practice. First, firms in Africa need to continue to focus on their human resource capacity development and staff training which is critical for product innovation. Similarly, African governments have to encourage and provide the resources particularly for technical education which will enhance the ability of firms to employ the skilled staff. More so firm competitiveness should be seen as a positive input into the product innovation process. Networking among firms in the same industry or even cross-collaborations should be encouraged and directed by public policy.

There are a few limitations to this study. Firstly, this study has depended on indices to come out with the results and this could present some technical challenges regarding the aggregation of the data. However, the GEI data has been known for its robust methodology and hence such doubts are minimised. Secondly, the unavailability of data for the 54 African countries presents a challenge in terms of the generalisation of the study. Finally, some exploratory study regarding the variables investigated could have provided a deeper and 
qualitative dimension to enrich the study. The findings from this study highlight some further research areas which future research could be focused. Firstly, future research of this kind in Africa could focus on other driving forces of product innovation such as energy, the cost of product innovation and even culture. Secondly, process innovation which is one of the major pillars of the GEDI, 2017 survey could also be explored in the context of Africa. 


\section{References}

Acemoglu, D., and Dan, C. 2015. Innovations by entrants and incumbents. Journal of Economic Theory 157: 255-294.

Al-Bader, S., Masum, H., Simiyu, K., Daar, A. S., and Singer, P. A. 2010. Science-based health innovation in sub-Saharan Africa. BMC International Health and Human Rights, 10 (1): 3-9.

Alegre, J., Lapiedra, R., and Chiva, R. 2006. A measurement scale for product innovation performance. European Journal of Innovation Management, 9 (4): 333-346.

Amankwah-Amoah, J., and Sarpong, D. 2014. The Battle of Brainpower: The role of market intermediaries in Lateral Hiring. Strategic Change, 23 (3): 237-251.

Atiase, Y. V., Mahmood, S., Wang, Y., and Botchie, D. 2018. Developing entrepreneurship in Africa: investigating critical resource challenges. Journal of Small Business and Enterprise Development, 25 (4): 644-666. Retrieved from https://doi.org/10.1108/JSBED-03-2017-0084

Audretsch, B. D., and Belitski, M. 2013. The missing pillar: the creativity theory of knowledge spillover entrepreneurship. Small Business Economics, 41: 819-836.

AU-NEPAD. 2014. African Innovation Outlook II. Pretoria: African Union-New Partnership for African Development.

Baer, J. 2012. Domain Specificity and the Limits of Creativity Theory. The Journal of Creative Behavior, 46 (1): 16-29.

Baldwin, C., and Hippel, E. V. 2011. Modelling a Paradigm Shift: From Producer Innovation to User and Open Collaborative Innovation. Organisation Science, 22 (6): 1399-1417.

Barasaa, L., Knoben, J., Vermeulen, P., Kimuyua, P., and Kinyanjuia, B. 2017. Institutions, resources and innovation in East Africa: A firm-level approach. Research Policy, 46: 280-291.

Barbot, B. 2018. Creativity and Self-esteem in Adolescence: A Study of Their Domain-Specific, Multivariate Relationships. Journal of Creative Behaviour, 1-14.

Barney, J. B. 1991. Firm resources and sustainable competitive advantage. Journal of Management, 17: 99-120.

Bengtsson, M., Raza-Ullah, T., and Vanyushyn, V. 2016. The Coopetition paradox and tension: The moderating role of Coopetition capability. Industrial Marketing Management, 53: 19-30.

Blonigen, B. A., Knittel, C. R., and Soderbery, A. 2017. Keeping it fresh: strategic product redesigns and welfare. International Journal of Industrial Organisation, 53: 170-214.

Botchie, D., Sarpong, D., and Bi, J. 2017. Technological inclusiveness: Northern versus Chinese induced technologies in the garment industry. Technological Forecasting and Social Change, 119: $310-322$.

Cardoso de Sousa, F., Pellissier, R., and Monteiro, I. P. 2012. Creativity, Innovation and collaborative organisations. The International Journal of Organization Innovation Vol 5 Num 1 Summer 2012, 5 (1): 26-64. 
Carlisle, S., Kunc, M., Jones, E., and Tiffin, S. 2013. Supporting innovation for tourism development through multi-stakeholder approaches: Experiences from Africa. Tourism Management, 35: 59-69.

Chatterji, K. A., and Fabrizio, R. K. 2014. Using Users: When does external Knowledge enhance Corporate Product innovation. Strategic Management Journal, 35: 1427-1445.

Chuang, L.-M. 2007. The Social Psychology of Creativity and Innovation: Process Theory Perspective. Social Behaviour and Personality, 35 (7), 875-888.

Colombo, M. G., Laursen, K., Magnusson, M., and Rossi-Lamastra, C. 2012. Introduction: Small Business and Networked Innovation: Organizational and Managerial Challenges. Journal of Small Business Management, 50 (2): 181-19.

Cooper, R. G., and Edgett, J. S. 2008. Maximising productivity in product Innovations. Research Technology Management, 51 (2): 47-58.

Costa, R. V., Fernández, F.J. C., and Dorrego, P. F. 2014. Critical elements for product innovation at Portuguese innovative SMEs: an intellectual capital perspective. Knowledge Management Research and Practice, 12: 322-338.

Cucculelli, M., Breton-Miller, L. I., and Miller, D. 2016. Product innovation, firm renewal and family governance. Journal of Family Business Strategy, 7: 90-104.

Cui, Y., Jiao, J., and Jiao, H. 2016. Technological innovation in Brazil, Russia, India, China, and South Africa (BRICS): An organizational ecology perspective. Technological Forecasting and Social Change, 107: 28-36.

Cusmano, L., Morrison, A., and Rabellotti. 2010. Catching up Trajectories in the Wine Sector: A Comparative Study of Chile, Italy, and South Africa. World Development, 38 (11): 15881602.

Czerwonka, M., and Karwowski, M. 2018. The Order Matters: Asking About Creative Activity Calibrates Creative Self-Concept. Creativity Research Journal, 30 (2): 179-186.

Deininger, M., Daly, S. R., Sienko, K. H., and Lee, J. C. 2017. Novice designers' use of prototypes in engineering design. Design Studies, 51:, 24-65.

Dittrich, K., and Duysters, G. 2007. Networking as a Means to Strategy Change: The Case of Open Innovation in Mobile Telephony. Journal of Product Innovation Management, 24: 510-521.

Duxbury, T. 2012. Creativity: Linking Theory and Practice for Entrepreneurs. Technology Innovation Management Review, 10-15.

Egbetokun, A., Atta-Ankomah, R., Jegede, O., and Lorenz, E. 2016. Firm-level innovation in Africa: overcoming limits and constraints. Innovation and Development, 6 (2), 161-174.

Engelma, R. M., Fracass, E. M., Schmidt, S., and Zen, A. C. 2017. Intellectual capital, absorptive capacity and product innovation. Management Decision, 55 (3): 474-490. 
Evanschitzky, H., Eisend, M., Calantone, R. J., and Jiang, Y. 2012. Success Factors of Product Innovation: An Updated Meta-Analysis. Journal of Product Innovation Management, 29 (1): 21-37.

Ferna'ndez-Mesa, A., Alegre-Vidal, J., Chiva-Go’mez, R., and Gutie'rrez-Gracia, A. 2013. Design management capability and product innovation in SMEs. Management Decision, 51 (3): 547565 .

Fichter, K. 2009. Innovation communities: the role of networks of promotors in Open Innovation. $R$ \&D Management, 39 (4): 357-371.

Fossas-Olalla, M., Minguela-Rata, B., López-Sánchez, J.-I., and Fernández-Menéndez, J. 2015. Product innovation: When should suppliers begin to collaborate? Journal of Business Research, 68: 1404-1406.

GEDI. (2017). Global Entrepreneurship Index. Washington, D.C.: GEDI.

Hecker, A., and Ganter, A. 2013. The Influence of Product Market Competition on Technological and Management Innovation: Firm-Level Evidence from a Large-Scale Survey. European Management Review, 10: 17-33.

Hemphälä, J., and Magnusson, M. (2012). Networks for Innovation - But What Networks and What Innovation? Creativity and Innovation Management, 21 (1): 3-16.

Hippel, E. V., de Jong, P. J., and Flowers, S. 2012. Comparing Business and Household Sector Innovation in Consumer Products: Findings from a Representative Study in the United Kingdom. Management Science, 59 (9): 1669-1681.

Hippel, V. E. (2011). People Don’t Need A Profi t Motive To Innovate. Harvard Business Review, 89 (11): 36-37.

Hoffmann, D. E., Ivcevic, Z., and Maliakkal, N. 2018. Creative Thinking Strategies for Life: A Course for Professional Adults Using Art. Journal of Creative Behaviour, 1-18.

Hofman, E., Halman, J. I., and Song, M. 2017. When to Use Loose or Tight Alliance Networks for Innovation? Empirical Evidence. Journal of Product Innovation Management, 34 (1): 81100.

Iizuka, M. P., and Gault, F. 2015. Innovation for Development in Southern and Eastern Africa: Challenges for Promoting STandI Policy-UNU-MERIT Policy Brief.

Im, S., Montoya, M. M., and Workman, J. P. 2013. Antecedents and Consequences of Creativity in Product Innovation Teams. Journal of Product Innovation Management, 30 (1): 170-185.

Ip, C. Y., Liang, C., Wu, S.C., Law, K. M., and Liu, H.C. 2018. Enhancing Social Entrepreneurial Intentions through Entrepreneurial Creativity: A Comparative Study Between Taiwan and Hong Kong. Creativity Research Journal, 30 (2): 132-142.

Kasirer, A., and Mashal, N. 2018. Fluency or Similarities? Cognitive Abilities that Contribute to Creative Metaphor Generation. Creativity Research Journal, 30 (2): 205-211. 
Konsti-Laakso, S., Pihkala, T., and Kraus, S. 2012. Facilitating SME Innovation Capability through Business Networking. Creativity and Innovation Management, 21 (1): 93-105.

Leenders, T. A., and Dolfsma, A. W. 2016. Social Networks for Innovation and New Product Development. Journal of Product Innovation Management, 33 (2): 123-13.

Lentz, R., and Mortensen, D. T. 2016. Optimal growth through product innovation. Review of Economic Dynamics, 19: 4-19.

Li, Y., Wang, J., Li, X., and Zhao, W. 2007. International Journal of Advanced Manufacturing Technology. Design creativity in product innovation, 33: 213-222.

Lyytinen, K., Yoo, Y., and Boland, J. R. 2016. Digital product innovation within four classes of innovation network. Information Systems Journal, 26: 47-75.

Minh, T. T., and Hjorts $\varnothing$, C. N. 2015. How Institutions Influence SME Innovation and Networking Practices: The case of Vietnamese Agribusiness. Journal of Small Business Management, $\mathbf{5 3}$ (1): 209-228.

Mohamud, M., and Sarpong, D. 2016. Dynamic capabilities: towards an organizing framework. Journal of Strategy and Management, 9 (4): 511-526.

Moses, C., Sithole, M. M., Blankley, W., Labadarios, D., Makelane, H., and Nkobole, N. 2012. The state of innovation in South Africa: Findings from the South African National Innovation Survey. South African Journal of Science, 108 (7): 2-5.

Mwiti, L. 2015. Science, technology and innovation in Africa: not always rosy, but it is about to be. from Mail and Guardian: https://mg.co.za/article/2015-03-27-00-science-technology-andinnovation-in-africa-not-always-rosy-but-it-is-about-to-be (accessed 24 July 2018)

Naghavi, A., and Ottaviano, G. 2009. Offshoring and product innovation. Economic Theory, 38, 517 532.

O’Regan, N. 2012. Entrepreneurship and Innovation: Overview. Strategic Change, 21 (6), 193-198.

Oluwatobi, S. E. 2015. Innovation in Africa: why institutions matter. South African Journal of Economics, 83 (3), 390-410.

Paliokaitè, A., Pačèsa, N., and Sarpong, D. 2014. Conceptualizing Strategic Foresight: An Integrated Framework. Strategic Change, 23 (4), 162-169.

Phillips, W., Lamming, R., and Caldwel, N. 2012. Customer-Supplier Relationships During the Process of Innovation: An Innovation Systems Approach. Strategic Change, 21 (6), 263-274.

Pittaway, L., Robertson, M., Munir, K., Denyer, D., and Neely, A. 2004. Networking and innovation: a systematic review of the evidence. International Journal of Management Reviews, 5 (3), $137-168$.

Robbins, P., and O'Gorman, C. 2015. Innovating the innovation process: an organisational experiment in global pharma pursuing radical innovation. RD Management, 45 (1), 76-93.

Sambharya, R., and Musteen, M. 2014. Institutional environment and entrepreneurship: An empirical study across countries. Journal of International Entrepreneurship, 12 (4): 314-330. 
Schumpeter, J. 1934. The Theory of Economic Development: An Inquiry intoProfits, Capital, Credit, Interest and the Business Cycle (Vol. 55). New Jersey: Transaction Publishers.

Smith, S., Smith, G., and Shen, Y.T. 2012. Redesign for product innovation. Design Studies, 33, 160184.

Story, V. M., Boso, N., and Cadogan, W. J. 2015. The Form of Relationship between Firm-Level Product Innovativeness and New Product Performance in Developed and Emerging Markets. Journal of Product Innovation Management, 32 (1): 45-64.

Valencia, J. C., Valle, R. S., and Jime'nez Jime'nez, D. 2010. Organizational culture as determinant of product innovation. European Journal of Innovation Management, 13 (4): 466-480.

West, J., and Boger, M. 2014. Leveraging External Sources of Innovation: A Review of Research on Open Innovation. Journal of Product Innovation Management, 31 (4): 814-831.

Wu, J. (2012). Technological collaboration in product innovation: The role of market competition and sectoral technological intensity. Research Policy, 41: 489- 496.

Zhang, J., Hoenig, S., Benedetto, A. D., Lancioni, A. R., and Phatak, A. 2009. What contributes to the enhanced use of customer, competition and technology knowledge for product innovation performance? A survey of multinational industrial companies' subsidiaries operating in China. Industrial Marketing Management, 38: 207-218.

Zhang, L.f., and Sternberg, J. R. 2011. Revisiting the Investment Theory of Creativity. Creative Research Journal, 23 (3): 229-238. 
Appendix 1: Model Summaries

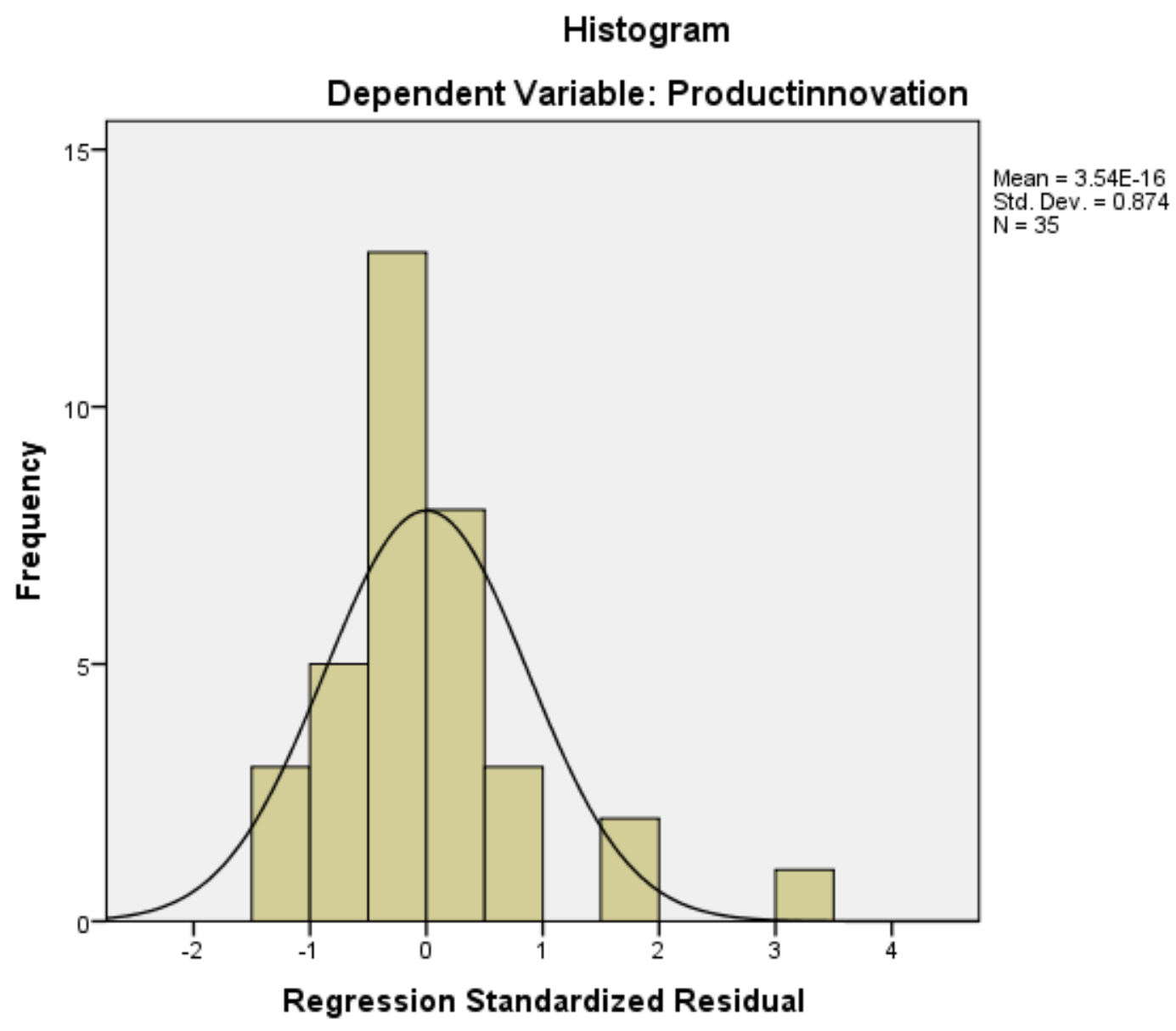

Scatterplot

Dependent Variable: Productinnovation

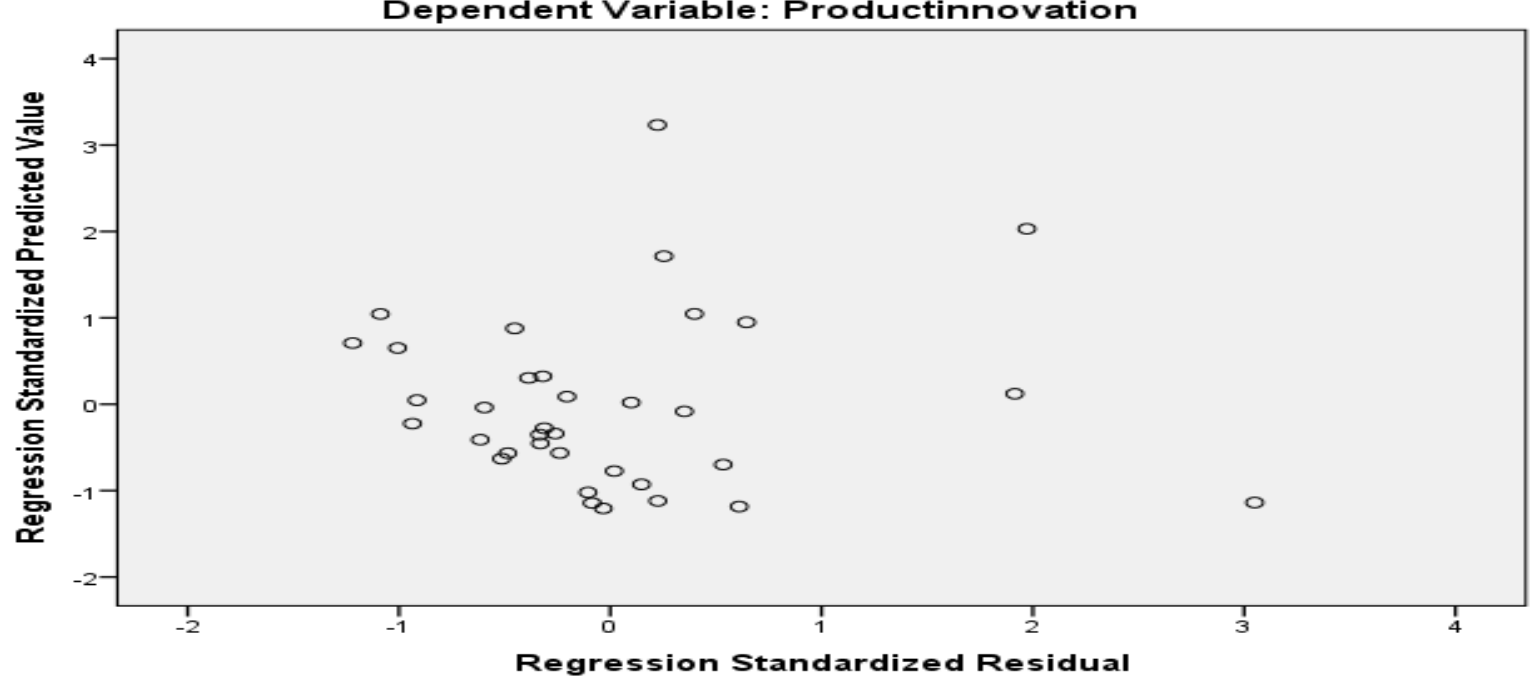




\begin{tabular}{|c|c|c|c|c|c|c|c|c|c|}
\hline \multicolumn{10}{|c|}{ Model Summary } \\
\hline \multirow[t]{2}{*}{ Model } & \multirow[t]{2}{*}{$\mathrm{R}$} & \multirow{2}{*}{$\begin{array}{c}\mathrm{R} \\
\text { Square }\end{array}$} & \multirow{2}{*}{$\begin{array}{l}\text { Adjusted R } \\
\text { Square }\end{array}$} & \multirow{2}{*}{$\begin{array}{c}\text { Std. Error of } \\
\text { the } \\
\text { Estimate }\end{array}$} & \multicolumn{5}{|c|}{ Change Statistics } \\
\hline & & & & & $\begin{array}{l}\text { R Square } \\
\text { Change }\end{array}$ & $\begin{array}{c}\mathrm{F} \\
\text { Change }\end{array}$ & $\mathrm{df1}$ & $\mathrm{df2}$ & $\begin{array}{c}\text { Sig. F } \\
\text { Change }\end{array}$ \\
\hline 1 & $.691^{\mathrm{a}}$ & .477 & .317 & .12103 & .477 & 2.968 & 8 & 26 & .017 \\
\hline
\end{tabular}

a. Predictors: (Constant), Population, Humancapital, GDP, Networking, Competition, FDI,

b. Dependent Variable: Product innovation

\section{Appenxdix II: Description of independent and dependent variables}

\begin{tabular}{|c|c|c|c|}
\hline Sub-Indices & Pillar Name & Description & Variables Used \\
\hline \multirow{3}{*}{$\begin{array}{l}\text { Independent } \\
\text { Variables }\end{array}$} & $\begin{array}{l}\text { Pillar 4; } \\
\text { Networking }\end{array}$ & $\begin{array}{l}\text { Combines two aspects of Networking: (1) a proxy for } \\
\text { the ability of firms to access and mobilise opportunities } \\
\text { and resources through networking and collaborations } \\
\text { and (2) ease of access to reach each other }\end{array}$ & $\begin{array}{l}\text { Know } \\
\text { entrepreneurs, } \\
\text { agglomeration } \\
\text { urbanisation, and } \\
\text { infrastructure }\end{array}$ \\
\hline & $\begin{array}{l}\text { Pillar 8: } \\
\text { Human } \\
\text { Capital }\end{array}$ & $\begin{array}{l}\text { Focus on quality of entrepreneurs as weighing percent } \\
\text { of start-ups by individuals with higher than secondary } \\
\text { education with a qualitative measure of the propensity } \\
\text { of firms in a country to train staff combined with } \\
\text { freedom of labour market }\end{array}$ & $\begin{array}{l}\text { Educational level, } \\
\text { the labour market, } \\
\text { staff training, labour } \\
\text { freedom }\end{array}$ \\
\hline & $\begin{array}{l}\text { Pillar 9: } \\
\text { Competitiven } \\
\text { ess }\end{array}$ & $\begin{array}{l}\text { Measures product or market uniqueness of start-ups } \\
\text { combined with the market power of existing } \\
\text { businesses and business groups as well as with } \\
\text { effectiveness of competitive regulation }\end{array}$ & $\begin{array}{l}\text { Competitors, } \\
\text { market dominance, } \\
\text { regulation }\end{array}$ \\
\hline $\begin{array}{l}\text { Dependent } \\
\text { Variable }\end{array}$ & $\begin{array}{l}\text { Pillar 10: } \\
\text { Product } \\
\text { Innovation }\end{array}$ & $\begin{array}{l}\text { Captures the tendency of entrepreneurial firms to } \\
\text { create new products weighing by technology transfer } \\
\text { capacity of a country }\end{array}$ & $\begin{array}{l}\text { New product, } \\
\text { technology transfer }\end{array}$ \\
\hline
\end{tabular}

\section{Appenxdix III: Description of control variables}

\begin{tabular}{|l|l|l|}
\hline Index & Description & Variables \\
\hline FDI & $\begin{array}{l}\text { Measures level of foreign direct investment into } \\
\text { various African enterprises }\end{array}$ & Level of foreign direct investment \\
\hline
\end{tabular}




\begin{tabular}{|l|l|l|}
\hline GDP & $\begin{array}{l}\text { Measures growth of Gross domestic product of } \\
\text { African countries }\end{array}$ & $\begin{array}{l}\text { The growth of gross domestic } \\
\text { product }\end{array}$ \\
\hline Population & Measures growth of the African population & Population growth \\
\hline
\end{tabular}

\section{Bibliographic Note:}

1. Victor Yawo Atiase

Victor Y. Atiase is currently a lecturer at the International Centre for Transformational Entrepreneurship, Coventry University, United Kingdom. His research and teaching cu across entrepreneurship, innovation studies, entrepreneurial finance and small business management in the African context.

\section{Dennis Yao Dzansi}

Dennis Yao Dzansi is a professor of entrepreneurship and Head of Department of the Business support Studies at the Faculty of Management Sciences, Central University of Technology, South Africa. His research and teaching cuts across entrepreneurship, corporate social responsibility, entrepreneurial finance and innovation.

\section{Corresponding Author:}

Name: Victor Yawo Atiase

Email: ac8946@ coventry.ac.uk 